\title{
ANALISIS SISTEM PENILAIAN KINERJA KARYAWAN STUDI PADA PT. TRIDHARMA KENCANA
}

\author{
Oleh: \\ Eko Setiobudi \\ Dosen Sekolah Tinggi Ilmu Ekonomi Tribuana Bekasi \\ Email: \\ ekosetiobudi@gmail.com
}

\begin{abstract}
ABSTRAK
Karyawan adalah aset bagi perusahaan. Oleh sebab itu, penilaian kinerja terhadap karyawan menjadi sangat penting untuk mengukur sistem tata kelola manajemen sumber daya manusia dalam rangka mencapai tujuan, visi dan misi perusahaan. Berbagai perusahaan terus mengembangkan sistem penilaian terhadap kinerja karyawannya. Salah satunya adalah PT. Tridharma Kencana, sebuah perusahaan EMS yang sudah beroperasi sejak puluhan tahun yang lalu. Penelitian dilakukan dengan menggunakan pendekatan kualitatif deskriptif. Pengambilan sampel penelitian dilakukan secara purposif. Pengumpulan data melalui wawancara dan observasi. Analisis data dilakukan dengan reduksi data, menyajikan data, dan membuat simpulan. Sejak tahun 2016, sistem penilaian kinerja karyawan dilakukan dengan mengunakan Key Performance Indicator (KPI), dimana proses penilaiannya dilakukan setiap 3 bulan sekali. KPI kemudian dikumpulkan selama satu tahun kemudian dibuat rata-rata atau rasionya. Aspek penilaian KPI yang dilakukan di PT. Tridharma Kencana meliputi beberapa aspek, yakni : (1) Value Acquisition Indicator, (2) General Performance Indicator, (3) Achievement Performance Indicator, (4) Personal Performance Indicator. Aspek-aspek ini kemudian diturunkan dalam indikator-indikator kinerja karyawan dengan kriteria SMART, yaitu specific, measurable, achievable, reasonable, time-based. Penilaian KPI di PT. Tridharma Kencana digunakan untuk mengukur kinerja orang per orang pada semua level dan grade jabatan. Selain itu juga digunakan untuk mengukur kinerja divisi, bagian dan departemen. Berdasarkan penelitian, KPI PT. Tridharma Kencana tahun 2016 diketahui hasilnya cukup baik dan memuaskan.
\end{abstract}

Kata Kunci : Manajemen SDM, Kinerja, Karyawan, KPI 


\section{A. PENDAHULUAN}

Manajemen sumber daya manusia merupakan bagian dari ilmu manajemen yang memfokuskan perhatiannya pada pengaturan peranan sumber daya manusia dalam kegiatan suatu perusahaan. Posisi vital sumber daya manusia, seringkali menempatkan manusia sebagai bagian penting dari asset perusahaan. Oleh sebab itu, pengelolaan dan pemeliharaan (retensi) karyawan menjadi salah satu kunci sukses bagi perjalanan sebuah perusahaan.

Disadari betul, dalam mencapai tujuannya suatu perusahaan memerlukan tata kelola sumber daya manusia, baik dalam koridor pengelolaan sistem, pengelolaan kinerja, yang kemudian tertuang dalam berbagai implementasi kegiatan, seperti pelatihan/training, studi banding, on job training, termasuk pengembangan motivasi dan aspek-aspek lainya. Hal ini akan menjadikan manajemen sumber daya manusia sebagai salah satu indikator penting pencapaian tujuan organisasi secara efektif dan efisien.

Eksistensi sumber daya manusia dalam kondisi lingkungan yang terus berubah tidak dapat dipungkiri, oleh karena itu dituntut kemampuan beradaptasi yang tinggi agar mereka tidak tergilas oleh perubahan itu sendiri. Sumber daya manusia dalam perusahaan harus senantiasa berorientasi terhadap visi, misi, tujuan dan sasaran organisasi di mana dia berada di dalamnya. Oleh sebab itu pengelolaan sumber daya manusia menjadi penting dalam kaitannya dengan pencapain visi, misi, tujuan dan sasaran perusahaan dapat tercapai lebih optimal dan memberikan gambaran kepada semua pelaku perusahaan.

\section{B. KAJIAN PUSTAKA}

\section{Kinerja}

Salah satu catatan penting dalam konteks pengelolaan sumber daya manusia adalah menyangkut dengan aspek kinerja. Kinerja merupakan sebuah proses yang dilakukan oleh sekelompok orang dalam sebuah perusahaan dalam upayanya untuk menciptakan suatu produk atau jasa. Kinerja biasanya identik dengan proses pekerjaan dikalangan karyawan suatu perusahaan. Karena kinerja inilah yang akan memberikan suatu hasil bagi perusahaan tersebut. Kinerja karyawan merupakan aspek penting dalam sebuah perusahaan. Karena hal inilah yang akan menentukan maju atau mundurnya suatu perusahaan. Apabila para karyawannya berkinerja buruk maka yang terjadi adalah kemerosotan pada perusahaannya. Hal ini juga akan berlaku sebaliknya, apabila para karyawannya merupakan para karyawan yang rajin dan senang berinovasi maka yang terjadi adalah kemajuan yang positif bagi perusahaan tersebut.

Berbagai program telah digunakan dan diterapkan diberbagai perusahaan untuk mendapatkan sebuah nilai yang lebih dihadapan para konsumennya dalam rangka untuk meningkatkan mutu produk dan jasa yang dihasilkan perusahaan seperti melalui penerapan program TQM (Total Quality Management) dan Penerapan program ISO (Internasional Standart Organization) yang sekarang memang harus diterapkan pada perusahaan-perusahaan swasta. Untuk menunjang program tersebut, karyawan diharuskan untuk mengikuti pelatihan dan 
menerapkannya dalam pekerjaannya. Dengan demikian akan mendorong munculnya produk baru dengan mutu yang baik dan harga yang terjangkau, khususnya untuk produk-produk yang banyak dibutuhkan oleh masyarakat Indonesia.

\section{Penilaian Kinerja}

Menurut Iqbal, Ahmad, Haider, Batool dan Ain (2011), kinerja organisasi yang baik mengacu pada kinerja karyawan yang baik pula. Kinerja karyawan yang baik tidak terjadi secara otomatis begitu saja. Aspek-aspek seperti standar manajerial, pengetahuan dan keterampilan, komitmen dan penilaian kinerja dapat mempengaruhi kinerja karyawan. Untuk menilai, dapat menggunakan Penilaian Kinerja atau Performance Appraisal (PA) sebagai salah satu metode dalam melakukan tolak ukur.

Penilaian Kinerja atau Performance Appraisal (PA) adalah sebuah sistem yang formal digunakan dalam beberapa periode waktu tertentu untuk menilai prestasi kerja seorang karyawan. Selain itu, penilaian kinerja dapat berfungsi untuk mengidentifikasi, mengobservasi, mengukur, mendata, serta melihat kekuatan dan kelemahan dari karyawan dalam melakukan pekerjaan. Penggunaan penilaian kinerja ini dapat meningkatkan performa kerjakaryawan. Penilaian kinerja benar-benar didesain sedemikian rupa untuk membantu perusahaan mencapai tujuan organisasi dan memotivasi performa karyawan. Kegunaan dalam penggunaan penilaian kinerja ini adalah untuk meningkatkan performa kerja dari karyawan. Penilaian kinerja benar-benar didesain sedemikian rupa untuk membantu perusahaan mencapai tujuan organisasi dan memotivasi performa karyawan.

Sementara itu, menurut Latham dan Weley dalam Mondy,W. dan Noe, R.M. (2005), penilaian kinerja adalah seperangkat interaksi formal yang terstruktur antara bawahan dan atasan, biasanya dalam bentuk wawancara periodik, dimana kinerja bawahan ditinjau dan dibahas, dengan penekanan pada identifikasi kelemahan dan kekuatan serta sebagai peluang untuk perbaikan kinerja dan pengembangan keterampilan.

Menurut Cascio (1989), agar penilaian kinerja dapat berjalan secara efektif maka ada beberapa hal yang perlu diperhatikan, yaitu:

a. Relevance. Hal ini menunjukkan bahwa harus ada keterkaitan atau hubungan yang jelas antar standar kinerja dengan tujuan organisasi, selain itu juga harus ada hubungan yang jelas antara unsur-unsur pekerjaan kritis yang diidentifikasi melalui analisis pekerjaan dan dimensi yang akan dinilai pada formulir penilaian.

b. Sensitivity. Menunjukkan bahwa sistem penilaian kinerja mampu membedakan karyawan yang efektif dan tidak.

c. Reliability. Untuk menghasilkan data yang dapat diandalkan, maka masing-masing penilai harus memiliki kesempatan yang cukup untuk mengamati apa saja yang telah dilakukan oleh seorang pekerja. Apabila tidak, maka seorang peneliti akan bingung dalam memberikan nilai, karena tidak biasa dengan keadaan tersebut.

d. Acceptability. Dalam prakteknya, acceptability adalah bagian yang paling penting. Program sumber daya manusia harus mendapatkan persetujuan 
dari orang-orang yang menggunakannya. Apabila tidak, maka dapat terjadi kecerdikan manusia akan digunakan untuk menggagalkan mereka.

e. $\quad$ Practicality. Ini berarti bahwa instrumen dalam penilaian kinerja harus mudah untuk dipahami baik bagi manajer ataupun bagi karyawan.

Penelitian ini dilakukan di PT. Tridharma Kencana, yakni sebuah perusahaan Electronic Manufacturing Services (EMS) yang selama ini mengerjakan melakukan perakitan terhadap produk-produk elektronik dan telekomunikasi, seperti LED TV, Smartphone, Modem dan lain sebagainya. Dengan jumlah karyawan yang cukup banyak, dan sudah beroperasi selama puluhan tahun, maka pemilihan PT. Tridharma Kencana sebagai obyek penelitian dirasakan cukup pas, untuk melakukan analisa terhadap kinerja karyawannya.

Rumusan masalah dari penelitian ini adalah penilaian kinerja dimana peneliti akan menganalisa bagaimana sistem penilaian kinerja yang dilakukan di PT. Tridharma Kencana. Adapun tujuan dari penelitian ini adalah untuk mendeskripsikan sistem penilaian kinerja dan kontribusi dari masing-masing departemen terhadap total kinerja perusahaan dalam rangka mencapai visi dan misi perusahaan di PT. Tridharma Kencana. Sistem analisis penilaian kinerja ini dilakukan di semua departemen, yang digunakan selama tahun 2016.

\section{METODE PENELITIAN}

Penelitian dilakukan dengan menggunakan pendekatan kualitatif deskriptif. Penelitian deskriptif adalah suatu bentuk penelitian yang ditujukan untuk mendeskripsikan fenomena-fenomena yang ada, baik fenomena alamiah maupun fenomena buatan manusia. Pendekatan kualitatif, yang merupakan metode-metode untuk mengeksplorasi dan memahami makna yang oleh sejumlah individu atau sekelompok orang dianggap berasal dari masalah sosial atau kemanusiaan. Proses penelitian kualitatif ini melibatkan upaya-upaya penting, seperti mengajukan pertanyaan-pertanyaan dan prosedur-prosedur, mengumpulkan data yang spesifik dari para partisipan, menganalisis data secara induktif mulai dari tema-tema khusus ke tema-tema umum, dan menafsirkan makna data. Laporan akhir untuk penelitian ini memiliki struktur atau kerangka yang fleksibel. Siapapun yang terlibat dalam bentuk penelitian ini harus menerapkan cara pandang penelitian yang bergaya induktif, berfokus terhadap makna individual dan menerjemahkan kompleksitas suatu persoalan.

Penelitian kualitatif berupaya mengambarkan dan menjelaskan perspektif dan sekaligus perilaku, dengan mengakui bahwa perilaku tidak hanya berhembus dari perspektif dan bisa juga tidak sesuai dengannya. Bahkan ketidaksesuaian semacam itu menjadi fokus utama bagi penelitian kualitatif. Dengan demikian, jenis penelitian kualitatif dapat digunakan untuk meneliti organisasi, kelompok dan individu. Selain itu, penelitian kualitatif ini memiliki tiga unsur utama, yakni; (1) data dan sumber data, (2) prosedur analisis dan interprestasi dan (3) laporan tertulis dan lisan.

Pada sisi lain, Hatch (2002) menegaskan bahwa beberapa karakteristik dari penelitian kualitatif, yaitu: (1) Pengaturan alami, (2) Perspektif peserta, (3) Peneliti sebagai pengumpulan data instrumen, (4) Diperpanjang tangan pertama engagement, (5) Sentralitas arti, (6) Keutuhan dan kompleksitas, (7) 
Subyektivitas, (8) Munculnya desain, (9) Analisis data induktif, (10) Refleksivitas.

Denzin \&Lincoln (2009) juga menegaskan bahwa penelitian kualitatif menekankan sifat realita yang terbangun secara sosial, hubungan erat antara peneliti dengan subyek yang diteliti, dan tekanan situasi yang membentuk penyelidikan. Para peneliti semacam ini mementingkan sifat penyelidikan yang sarat nilai. Pendapat tersebut tidaklah berlebihan karena, menurut Rossi dan Freeman (1998), dalam penelitian kualitatif instrumen pokoknya adalah peneliti, sehingga tidak mustahil akan dapat mengungkap latar-latar perilaku dan pengalaman manusiawi dari kerangka acuan subjek itu sendiri.

Pengambilan sampel penelitian dilakukan secara purposif karena dalam penelitian kualitatif apa yang akan dicari adalah masalah yang alami sehingga tidak semua orang dapat dijadikan sampel. Penelitian kualitatif juga tidak terlalu dibutuhkan random sampling atau pemilihan secara acak terhadap para partisipan atau informan dan lokasi penelitian. Karenanya pembahasan mengenai informan atau partisipan dan lokasi penelitian dapat mencakup empat aspek: (1) lokasi penelitian, (2) aktor, (3) peristiwa dan, (4) proses. Jika dikaji dari perspektif ini, sample penelitian yang dijadikan sebagai informan dalam penelitian ini terdiri dari beberapa kelompok, yakni: (1) Kepala Departemen; (2) Kepala Divisi dan ; (3) Manager dan Asisten Manager.

Adapun pembatasan jumlah informan atau sampel sebagai sumber data/informasi atau subjek penelitian sebanyak 20 orang. Jumlah ini dianggap cukup dan sejalan dengan pendapat Emzir (2012), yang peneliti biasanya melakukan 20-30 wawancara berdasarkan beberapa pertemuan di lapangan untuk mengumpulkan data. Jumlah ini juga dirasa telah memadai sebab: (1) informasi yang diperoleh dari informan lain telah jenuh atau dengan kata lain hanya mengulang apa yang telah disampaikan oleh informan sebelumnya dan (2) yang terpenting dalam penelitian kualitatif, bukanlah jumlah orangnya, namun kedalaman (depth), kekayaan (richness), dan kompleksitas (complexity) informasi yang dimiliki informan. Hal ini juga sejalan dengan proses dan tekhnis penyampelan berbuka sebagaimana yang disampaikan oleh Strauss dan Corbin (2003).

Proses pengambilan data primer yang digunakan oleh peneliti adalah hasil dari wawancara dengan informan serta observasi lapangan. Data sekunder adalah data-data perusahan yang diberikan kepada peneliti, maupun buku, dan jurnal serta koran.

Dalam melakukan penelitian ini, peneliti menggunakan beberapa cara dalam pengumpulan data, yaitu:

1. Wawancara

Teknik wawancara adalah teknik mengumpulkan data atau informasi dengan cara bertatap muka langsung dengan informan agar mendapatkan data lengkap dan mendalam. Wawancara ini dilakukan dengan frekuensi tinggi (berulang-ulang) secara intensif (Sugiyono: 2011). Peneliti akan melakukan wawancara semi terstruktur, untuk mendapatkan ide-ide yang lebih terbuka dan mendalam. Oleh karena itu peneliti menyiapkan pedoman wawancara.

2. Observasi

Definisi Observasi lapangan atau pengamatan lapangan (field observation) adalah kegiatan yang setiap saat dilakukan, dengan kelengkapan panca indra yang 
dimiliki. Selain dengan membaca Koran, mendengarkan radio, menonton televisi atau berbicara dengan orang lain, kegiatan obsevasi merupakan salah satu kegiatan untuk memahami lingkungan (Sugiyono : 2011). Peneliti akan melakukan observasi langsung di lapangan tempat lokasi penelitian. Tujuan observasi adalah agar peneliti dapat melihat langsung keadaan yang terjadi dalam internal dan eksternal perusahaan.

Teknik analisis data dalam penelitian kualitatif menurut Creswell (2003) dilakukan melalui langkah-langkah : Langkah (1) mengolah dan mempersiapkan data untuk dianalisis. Langkah (2) Membaca keseluruhan data. Langkah (3) menganalisis lebih detail dengan meng-coding data. Langkah (4) terapkan proses coding untuk mendeskripsikan setting, orang-orang kategori-kategori dan tematema yang akan dianalisis. Langkah (5) tunjukkan bagaimana deskripsi dan tematema ini akan disajikan kembali dalam narasi/laporan kualitatif. Sementara Miles dan Huberman menegaskan bahwa ada tiga tahapan dalam analisis data, yaitu :

1. Reduksi data (Data Reduction)

Setelah data dikumpulkan, peneliti melakukan seleksi data sesuai dengan fokus penelitian. Data yang kurang relevan atau kurang berhubungan dengan fokus penelitian direduksi agar lebih mudah dalam meringkas dan membuat abstraksi terhadap data mentah, sehingga menjadi jelas. Reduksi data ini merupakan proses pemilihan, memfokuskan pada penyederhanaan, pengabstraksian dan transformasi data mentah yang muncul dari data catatan-catatan tertulis di lapangan. Reduksi data merupakan bentuk analisis yang menajamkan hal-hal yang penting, membuang hal-hal yang tidak relevan dengan fokus penelitian agar sistematis dan bermakna.

2. Menyajikan data (Display Data)

Penyajian data merupakan proses penyampaian sejumlah inforyang sudah disusun, yang memungkinkan untuk menarik kesimpulan dan pengambilan tindakan. Penyajian data merupakan gambaran sekeseluruhan dari sekelompok data yang diperoleh agar mudah dibaca secara menyeluruh. Pada tahap ini data dapat disajikan dalam bentuk narasi, matriks, grafik dan didiskusikan dengan berbagai pihak dan sumber. Dengan menyajikan data, peneliti dapat memahami apa yang terjadi dalam penelitian baik menyangkut validitas data maupun hal-hal yang kurang dalam penelitian.

\section{Membuat simpulan (Conclusion drawing/Verification)}

Pada tahap ini peneliti membuat simpulan dan memverifikasi serta mencocokkan kembali pada data atau hasil lapangan atau menelaah dengan sejawat. Kemudian diproses agar menjadi data yang siap disajikan untuk selanjutnya dibuat kesimpulan hasil penelitian. Kesimpulan merupakan suatu konfigurasi yang utuh. Selanjutnya dijelaskan bahwa analisis data ini dilakukan semenjak pengurnpulan data, artinya tidak harus menunggu data itu terkumpul semua tetapi dalam waktu proses pengurnpulan data pun dapat dilakukan analisis data.

\section{HASIL DAN PEMBAHASAN}

Proses penilaian kinerja di PT. Tridharma Kencana terus mengalami perubahan menuju kepada arah perbaikan. Artinya, system tersebut tidak langsung sempurna, melainkan melalui tahapan pembaharuan dan perbaikan dari tahun ke tahun. Form penilaian kinerja sendiri dibuat oleh bagian HRD dengan 
menyesuaikan standart ISO 9001. Sistem penilaian kinerja yang dilakukan di perusahaan adalah sama. Penilaian kinerja dilakukan oleh atasan ke bawahan.

Dari mulai Kepala Departemen, Kepala Devisi, Manajer, Asisten Manajer, Supervisor, Asistem Supervisor sampai kepada karyawan yang paling bawah atau yang lazim disebut dengan istilah operator. Perbedaan penilaian kinerja antar masing-masing divisi yaitu perbedaan aspek/indikator yang dinilai, dimana menyesuaikan dengan tugas yang dilaksanakan.

Sejak tahun 2016, system penilaian kinerja karyawan dilakukan dengan mengunakan Key Performance Inddicator (KPI), dimana proses penilaianya dilakukan setiap 3 bulan sekali. Dan selama kemudian dikumpulkan selama satu tahun dan di buat rata-rata atau rasio-nya selama satu tahun. Dari hasil penilaian satu tahun inilah, yang menjadi dasar bagi manajemen perusahaan untuk memberikan reward maupun punishment.

Menurut manajemen dan para kepala departemen, perubahan system penilaian kinerja karyawan dengan mengunakan KPI bertujuan agar dapat mengetahui kinerja seorang karyawan secara lebih tepat, focus dan terukur. Hal ini katena dalam KPI terdapat dua aspek yang diukur dalam sistem penilaian karyawan yaitu aspek kompetensi dan aspek hasil. Kompetensi dapat diketahui dengan melakukan penilaian kompetensi, aspek hasil dapat diketahui melalui penilaian serangkaian indikator kinerja yang tepat yang disebut dengan KPI atau indikator kinerja utama. Hal ini berbeda jika fokus penilaian kinerja lebih berdasar pada aspek hasil karena kebanyakan penilaian kinerja karyawan (aspek hasil) seringkali dihadapkan pada masalah subyektivitas karena tidak adanya indikator kinerja yang terukur dan objektif.

Oleh sebab itu, identifikasi terhadap indikator-indikator kunci dalam KPI secara tepat, diharapkan proses pembinaan kinerja pegawai dapat dilakukan dengan optimal, obyektif dan memberikan kontribusi positif bagi kinerja bisnis perusahaan. KPI itu sendiri adalah ukuran atau indikator yang akan memberikan informasi sejauh mana kita telah berhasil mewujudkan sasaran strategis yang telah kita tetapkan. KPI adalah ukuran spesifik tentang kinerja organisasi dalam wilayah bisnisnya. Ukuran tersebut dapat berupa financial maupun non financial yang dapat digunakan untuk mengukur kinerja strategis organisasi/perusahaan.

Sebagai alat ukur kinerja strategis organisasi, KPI dapat mengindikasikan kesehatan dan perkembangan organisasi, dan atau keberhasilan kerja dalam mewujudkan tujuan atau sasaran perusahaan. Dalam menyusun KPI kita harus sebaiknya menentapkan indikator kinerja yang jelas, spesifik dan terukur (measurable). KPI juga sebaiknya harus dinyatakan secara eksplisit dan rinci sehingga menjadi jelas apa yang diukur. Pada sisi lain, biaya untuk mengidentifikasi dan memonitor KPI sebaiknya tidak melebihi nilai yang akan diketahui dari pengukuran tersebut dan hindari pengukuran yang berlebihan yang tidak banyak memberi nilai tambah.

Aspek penilaian KPI yang dilakukan di PT. Tridharma Kencana meliputi beberapa aspek, yakni :

1. Value Acquisition Indicator. Aspek ini melakukan penilaian terhadap kategori-kategori :

a. Ketekunan

b. Dinamis 
c. Kualitas.

2. General Performance Indicator. Aspek ini melakukan penilaian terhadap kategori-kategori:
a. Kepemimpinan
b. Komunikasi
c. Disiplin
d. Keahlian tekhnis
e. Pengembangan diri

3. Achievement Performance Indicator. Aspek ini melakukan penilaian terhadap kategori-kategori :
a. Performa penjualan
b. Keuangan
c. Produksi (Hasil produk)
d. Pengelolaan SDM

4. Personal Performance Indicator. Aspek ini melakukan penilaian terhadap kategori-kategori:
a. Keselamatan kerja
b. Proses produksi
c. Arus informasi
d. Inventori asset
e. Hubungan industrial/lingkungan/budaya kerja

Aspek dan kategori-kategori tersebut di atas, kemudian diturunkan dalam indikator-indikator kunci yang digunakan sebagai dasar untuk melakukan pengukuran terhadap kinerja karyawan dalam semua level dan semua departemen/divisi. Indikator-indikator dalam KPI yang digunakan di PT. Tridharma Kencana menurut semua informan juga sudah mengikuti kriteria SMART, yaitu :

a. Specific, dimana target pencapaian KPI harus dirumuskan dengan jelas dan specific, sehingga dapat dipahami dengan mudah oleh seluruh anggota organisasi.

b. Measurable, dimana setiap KPI (baik ukuran kuantitatif maupun kualitatif) telah ditentukan informasi tentang jenis data-data yang akan digali, sumber data, dan cara mendapatkan data tersebut.

c. Achievable, dalam hal ini dapat dicapai untuk menghindari pengaturan terlalu tinggi atau terlalu rendah.

d. Reasonable, dimana indikator kinerja harus sesuai dengan fungsi dan tanggung jawab jabatannya, memiliki alasan dalam pencapaian suatu target tertentu.

e. Time-based, memfokuskan adanya batas waktu, dimana penyelesaian indikator kinerja dilakukan pada periode waktu tertentu.

Selain itu, pengunaan KPI sebagai system untuk melakukan penilaian terhadap kinerja karyawan juga dirasakan cukup komperhensif, mengingat banyaknya jumlah karyawan yang berkerja di PT. Tridharma Kencana.Dan sebagai gambaran, berikut disajikan jumlah karyawan di PT. Tridharma Kencana selama tahun 2016, dari bulan ke bulan. 


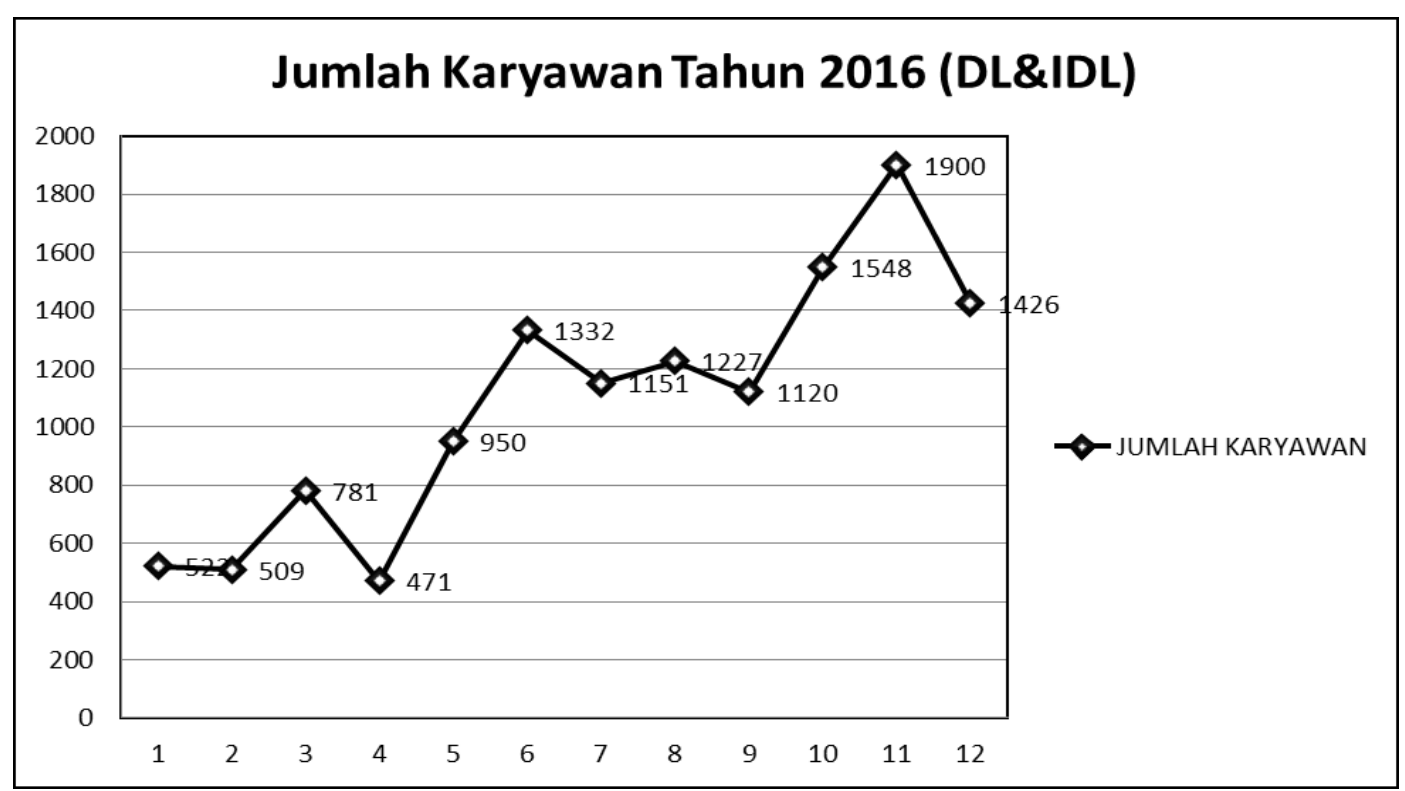

Sumber : Data Karyawan PT. Tridharma Kencana 2016

Gambar 1.

Jumlah Karyawan (Direct Labour/DL dan Indirect Labour/IDL) dari Januari-Desember 2016

Berdasarkan pada data tersebut di atas, dapat dilihat bahwa karyawan di PT. Tridharma Kencana terus mengalami tren peningkatan secara kuantitas. Dengan demikian, system penilaian kinerja karyawan dengan mengunakan system penilaian kinerja berdasarkan pada KPI memang dirasakan cukup tepat. Sehingga semua karyawan memiliki kesempatan dan indikator kinerja yang sama, tidak lagi subyektif berdasarkan pada hasil kerja.

Dan untuk dapat melihat atau mengukur efektifitas penilaian kinerja karyawan di PT. Tridharma Kencana dengan system penilaian berbasis pada KPI, berikut adalah contoh hasil penilaian kinerja karyawan.

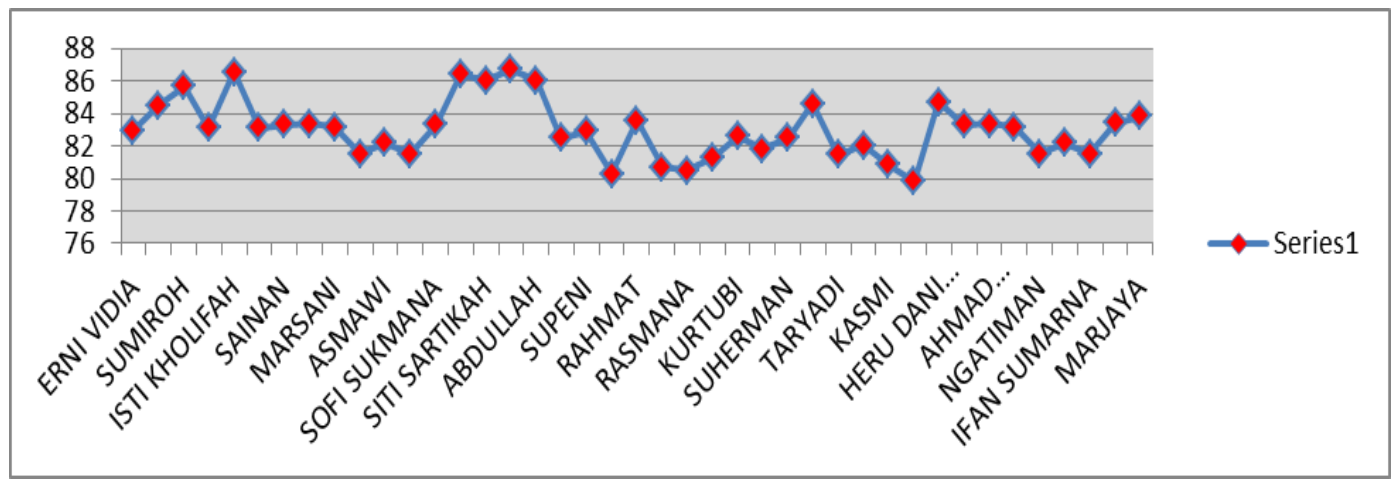

Sumber : Hasil KPI PT. Tridharma Kencana 2016

Gambar 2

Contoh Hasil KPI Karyawan untuk Level Operator 
Berdasarkan pada gambar tersebut di atas, maka semua karyawan sampai level yang paling bawah juga dapat dilakukan penilaian secara efektif dan terukur jika mengunakan system penilaian KPI.

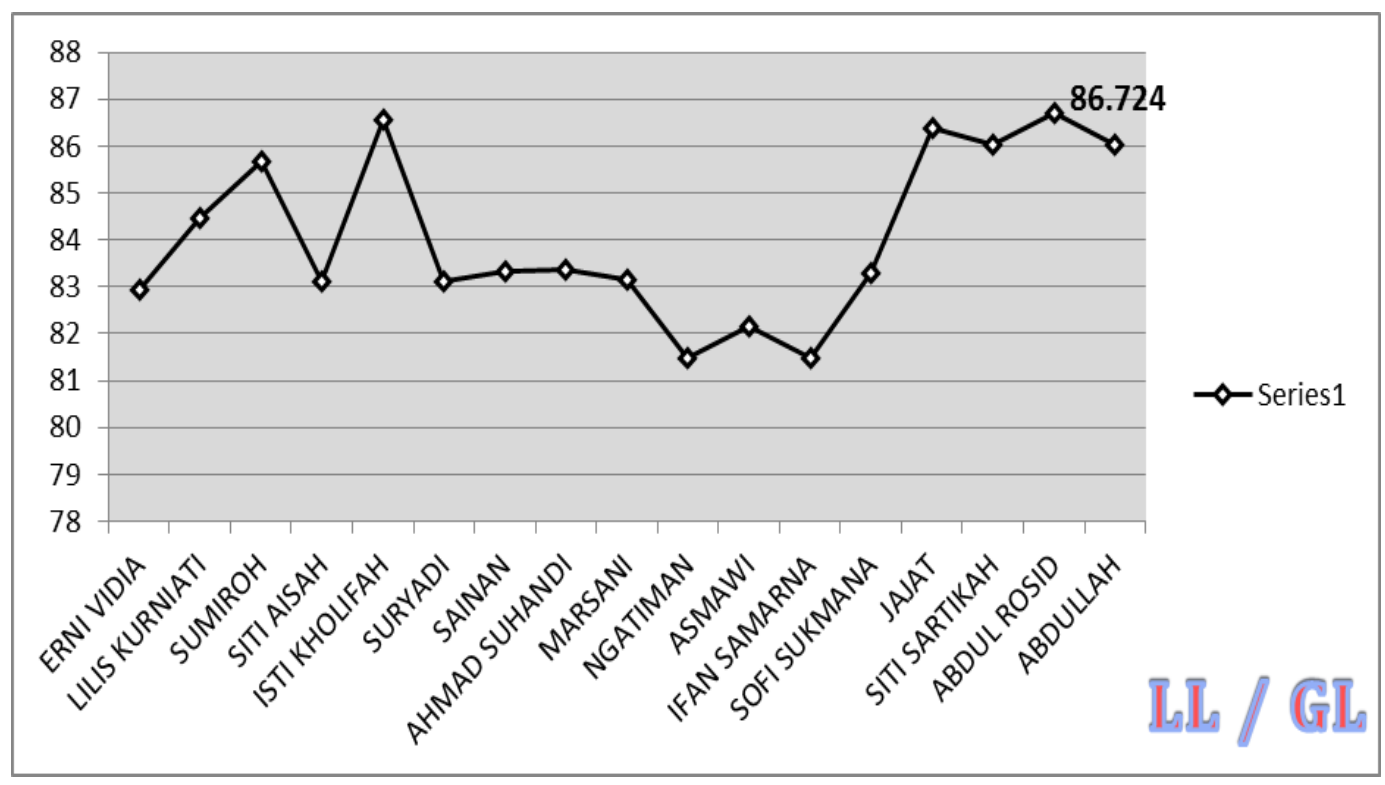

Sumber : Hasil KPI PT. Tridharma Kencana 2016

Gambar 3.

Contoh Hasil KPI Karyawan Untuk Level Leader

(Line Leader/LL dan Group Leader/GL)

Bukan hanya level karyawan paling bahwa yakni operator, system penilaian berdasarkan system KPI ternyata juga efektif untuk melakukan penilaian terhadap level leader, baik Line Leader (LL) maupun Group Leader (GL).

Sistem penilaian dengan system KPI, selain dapat mengukur kinerja orang per orang, juga bisa dilakukan untuk melakukan pengukuran kinerja secara kelompok, baik itu divisi, bagian maupun departemen. Dan berdasarkan pada hasil penilaian dengan system KPI yang digunakan di PT. Tridharma Kencana pada tahun 2016, dapat disampaikan sebagai berikut : 
1. Kontribusi masing-masing divisi berbasis pada supervisor terhadap total kinerja perusahaan

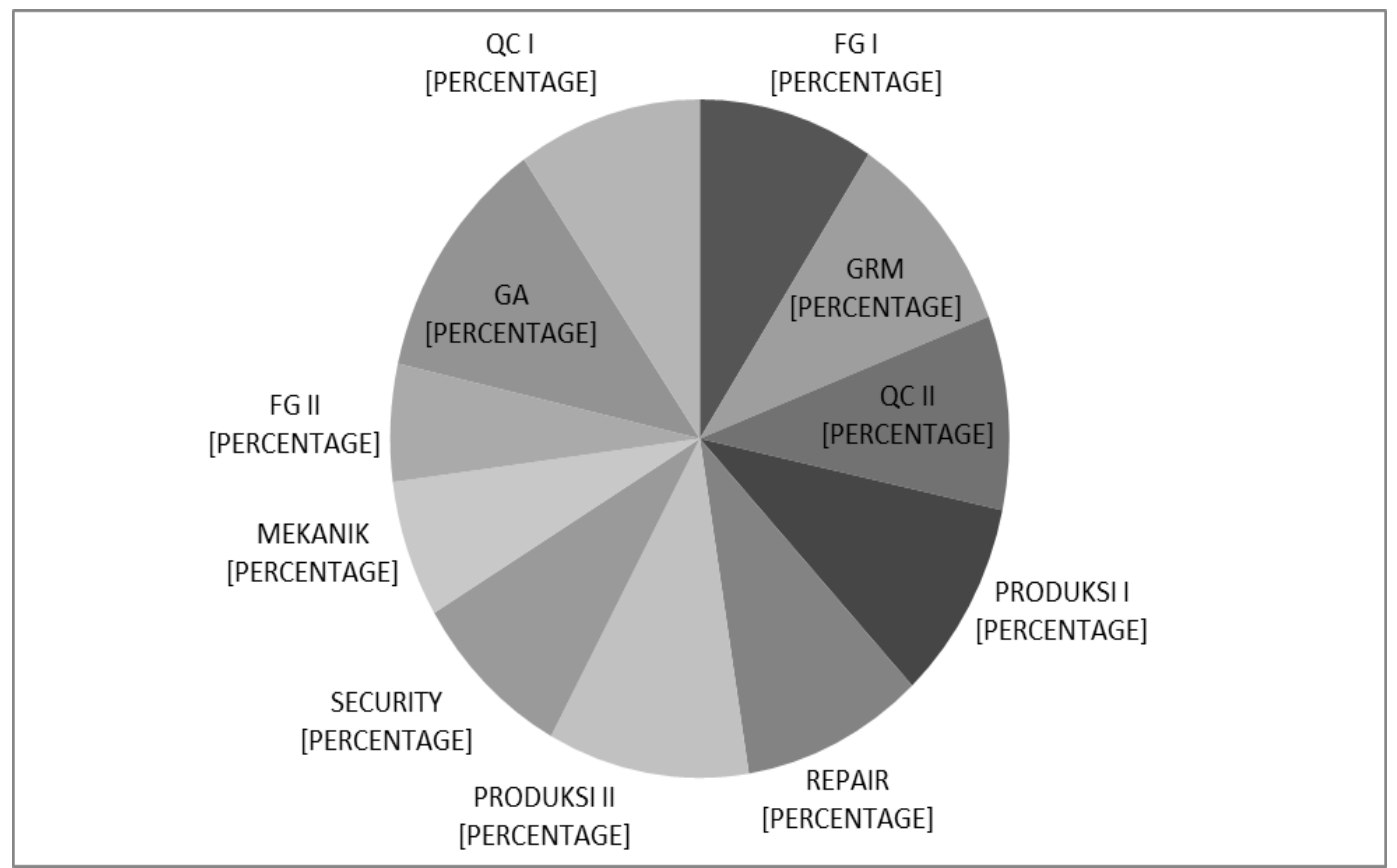

Sumber : Hasil KPI PT. Tridharma Kencana 2016

\section{Gambar 4}

\section{Kontribusi Masing-Masing Divisi Terhadap Total Kinerja Perusahaan}

Berdasarkan pada data tersebut di atas, dapat diketahui bahwa kontribusi divisi General Affair (GA) memiliki kontribusi terbesar terhadap total kinerja perusahaan, yakni sebesar 12\%. Kemudian disusul oleh Divisi Produksi I, Divisi Produksi II dan Divisi Gudang Row Material (GRM) yang masing-masing berkontribusi sebesar 10\%.Sementara divisi yang memberikan kontribusi terendah adalah divisi mekanik, yakni sebesar $7 \%$.

2. Kontribusi masing-masing departemen terhadap total kinerja perusahaan.

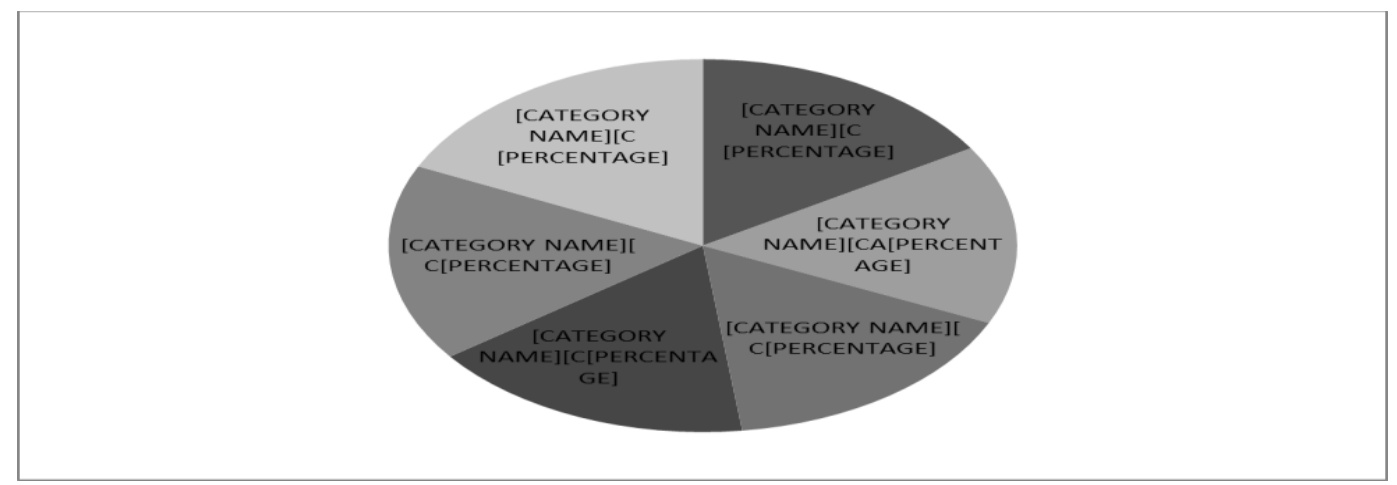

Sumber : Hasil KPI PT. Tridharma Kencana 2016

Gambar 5.

Kontribusi Masing-masing Departemen terhadap Total Kinerja Perusahaan 
Berdasarkan pada data tersebut di atas, departemen yang memberikan kontribusi terbesar terhadap total kinerja perusahaan sepanjang tahun 2016 adalah Departemen Logistik yakni sebesar $18 \%$, kemudian Departemen Accounting dan Departemen Financial Control sebesar 17\%, Departemen HRD, Riset \& Development serta Departemen Factory masing-masing memberikan kontribusi sebesar $16 \%$.

Berdasarkan pada hasil penilaian KPI PT. Tridharma Kencana untuk periode tahun 2016, dapat disimpulkan bahwa kinerja semua karyawan di PT. Tridharma Kencana dikategorikan cukup baik dan memuaskan. Dengan resume indicator KPI sebagai berikut :

1. Nilai rata-rata semua karyawan (operator dan officer) adalah 82,83

2. Nilai rata-rata operator adalah 74,81

3. Nilai rata-rata office dan departemen adalah 90,90

4. Hanya ada satu divisi yang memiliki nilai rendah, yakni unit divisi mekanik, dimana nilai unit departemen ini adalah 51,63.

Dengan demikian, jelas bahwa system penilaian kinerja karyawan di PT. Tridharma Kencana sudah cukup tepat, yakni mengunakan system penilaian KPI, sebagai alat pengukuran kinerja karyawan yang paling konperhensif dan terukur. Sehingga kesan penilaian secara subyektif berdasarkan pada hasil kerja dapat dihindari.

\section{E. SIMPULAN}

Sistem penilaian kinerja karyawan di PT. Tridharma Kencana terus mengalami peerubahan menuju ke arah perbaikan. Jika sebelumnya mengunakan form penilaian sederhana, sekarang sudah mengunakan system penilaian kinerja melalui system KPI dengan mengacu pada implementasi pelaksanaan ISO 9001.

Sistem KPI dilakukan setiap 3 bulan sekali yang dikelola oleh departemen HRD, yang kemudian penilaian satu tahun disatukan untuk mendapatkan rasio atau rata-rata penilaian kinerja karyawan di PT. Tridharma Kencana dari semua level, baik atasan (Direktur) sampai pada level karyawan yang paling bahwa yakni operator.

Aspek-aspek utama dalam penilaian karyawan adalah ;(1) Value Acquisition Indicator, (2) General Performance Indicator, (3) Achievement Performance Indicator, (4) Personal Performance Indicator. Aspek-aspek ini kemudian diturunkan dalam indikator-indikator kinerja karyawan dengan kriteria SMART, yaitu specific, measurable, achievable, reasonable, time-based. 


\section{DAFTAR PUSTAKA}

Cascio,W,F.(1998).ManagingHumanResources.NewYork:McGraw-HillInc.

Creswell, John W. (2014), Research Design, Pendekatan Kualitatif, Kuantitatif dan Mixed (Terjemahan Edisi Ketiga), Yogyakarta: Pustaka Pelajar.

Emzir.(2012), Metodologi Penelitian Pendidikan Kuantitatif \& Kualitatif, Edisi Revisi, Jakarta; PT RajaGrafindo Persada.

Hatch, J. Amos. (2002), Doing Qualitative Research In Education Setting, New York : State University Of New York Press.

Iqbal, Ahma, Haider, Batool \&Ain.(2013).Impactofperformance appraisal on employees performanceinvolvingtheModeratingRoleofMotivation,3,37-56, RetrievedMarch21,2014,fromProQuest.

Mondy,W.danNoe,R.M.(2005).HumanResourceManagement $\left(9^{\text {th }}\right.$ Edition).NewJer sey:PearsonPrenticeHall.

Norman K. Denzin \& Yvonna S. Lincoln (2009), Handbook of Qualitative Research (terjemahan), Yogyakarta : Pustaka Pelajar.

Peter H. Rossi, Howard E. Freeman \& Mark W. Lipsey (1998), Evaluation, A Systematic Approach Sixth Edition, California: SAGE Publications.lnc.

Sugiyono,(2011).Metode Penelitian Kuantitatif, KualitatifdanR\&D, Bandung: Alfabeta.

Straus, Anselm dan Corbin,Juliet.(2003), Dasar-dasar Penelitian Kualitatif: Tatalangkah dan Teknik-teknik Teoretisasi Data, Penerjemah, Muhammad Shodiq dan Imam Mutaqien, Yogyakarta: Pustaka Pelajar. 